\title{
Revegetation of Degraded Winterfat Communities
}

\section{By Charlie D. Clements, James A. Young, Dan N. Harmon, and Gary McCuin}

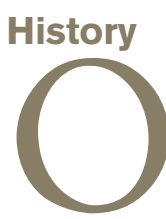

$\mathrm{n}$ salt desert ranges in the US intermountain area, pioneer ranchers were astounded to observe cattle and sheep readily browsing a native shrub now known as winterfat (Krascheninnikov lanata). ${ }^{1}$ Many of the shrubs growing in the salt desert environments have spines, modified leaves that impede browsing animals like cattle. However, winterfat does not possess such deterrents. This silver-gray shrub is a component of a variety of salt desert plant communities in Nevada, including lake plains and alluvial fans where it often dominates extensive areas along with bud sage (Artemisia spinescens) and needle-and-thread grass (Hesperostipa comata) or desert needlegrass (Achnatherum speciosum; Fig. 1). Pioneer ranchers were doubly astounded when they observed the condition of livestock that wintered on this shrub. Cattle came off the range in the early spring in excellent condition, so it was natural that they applied the common name winterfat to this species.

Winterfat first came to the attention of North American botanists in the material collected by Lewis and Clark.

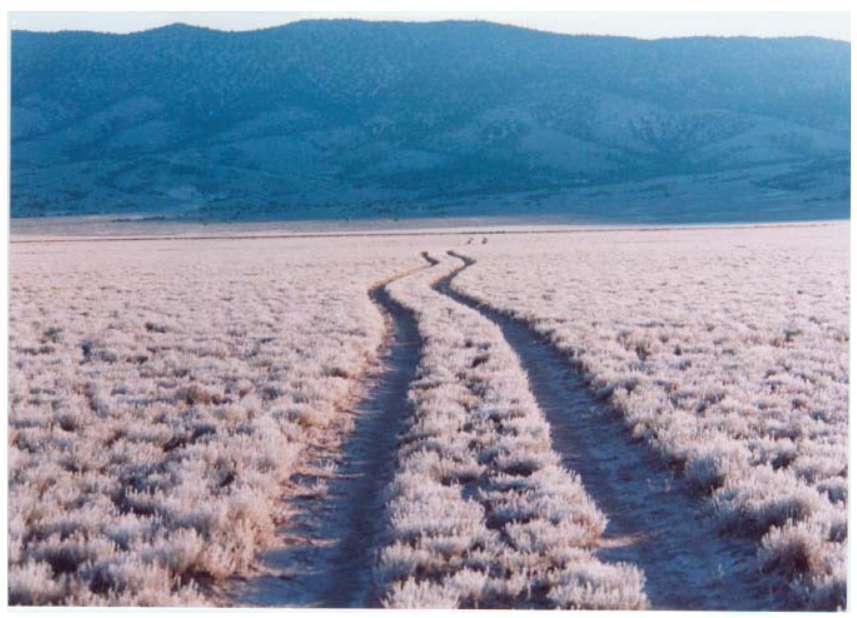

Figure 1. Excellent stand of winterfat adjacent to our Spring Valley South exclosure. There are nearly 300,000 winterfat plants per acre in this excellent stand.
Using this material Pursh described the shrub winterfat as Eurotia lanata. The first generation of range managers associated this scientific name with a widely occurring, highly important species of the western range suitable for grazing and browsing. Pursh did not realize that similar shrubs occurred in Eastern Europe and into central Asia. After an intermediate stop at Ceratoides lanata, the winterfat scientific name became a tongue twisting, memory-challenging Krascheninnikovia lanata in honor of the Russian botanist Stephan Krascheninnikov.

Winterfat, also referred to as white sage, is a member of the Chenopod or Goosefoot family that in the salt deserts includes such landscape characterizing species as shadscale (Atriplex confertifolia), Bailey's greasewood (Sarcobatus baileyi), and black greasewood (Sarcobatus vermiculatus). These shrubs are sufficiently spiny to discourage browsing or even cause mechanical injury to browsing animals. Black greasewood is poisonous to ruminants, especially when browsed during early spring. Livestock on winter ranges obtain digestible protein by licking the seeds of these species from the soil surface. This family contains important species suitable for grazing and browsing, such as four-wing saltbush (Atriplex canescens), green molly (Bassia americana), and 'Immigrant' forage kochia (Bassia prostrata). Winterfat occurs in semi-arid to temperate regions of western North America from Canada down to Mexico in many different plant communities. Winterfat is an important browsing plant for native wildlife species such as bighorn sheep, Rocky Mountain elk, and desert tortoise. The nutritional value of winterfat is rated at above average, with crude protein ranging from $14 \%$ in the winter months to $21 \%$ in spring and early summer months. ${ }^{2}$

In central and eastern Nevada many winterfat communities are dying and are being replaced by the exotic, invasive weed halogeton (Halogeton glomeratus). Halogeton, also a member of the Chenopod family, is an annual weed that is poisonous to sheep. Most range scientists believe that halogeton is not killing winterfat but is moving into areas where winterfat has died out, although halogeton may compete 
with the recruitment of winterfat seedlings. Due to widespread concern about the loss of winterfat communities, the Ely District of the Bureau of Land Management (BLM), US Department of Interior, asked for our cooperation to examine the possibilities for restoring or revegetating these degraded winterfat communities.

The BLM Ely District selected four sites in which they would like to reverse the trend of winterfat loss and restore or revegetate these habitats to desirable vegetation rather than halogeton. We initiated replicated seeding trials at each of these four sites in the fall of 1999. Seven separate species, including winterfat, were used.

\section{Methods, Results, and Discussion}

During the fall of 1999 we established and seeded plots at four separate study sites. Each plot received the following treatments:

1) Broadcast seeding of winterfat, 5 pounds per acre $(3.4 \mathrm{~kg} / \mathrm{ha})$ rate, drill seeding (rangeland drill)

2) Indian ricegrass (Achnatherum hymenoides), 2 pounds per acre $(2.26 \mathrm{~kg} / \mathrm{ha})$

3) Squirreltail (Elymus elymoides), 4 pounds per acre $(4.54 \mathrm{~kg} / \mathrm{ha})$

4) Robust needlegrass (Achnatherum robustum), 7 pounds per acre $(7.94 \mathrm{~kg} / \mathrm{ha})$

5) Siberian wheatgrass (Agropyron fragila subsp. sibericum), 7 pounds per acre $(7.94 \mathrm{~kg} / \mathrm{ha})$

6) 'Hycrest' crested wheatgrass (Agropyron cristatum), 7 pounds per acre $(7.94 \mathrm{~kg} / \mathrm{ha})$

7) 'Immigrant' forage kochia, 1 pound per acre $(1.13 \mathrm{~kg} / \mathrm{ha})$

Each treatment measured 10 feet by 150 feet $(33 \mathrm{~m}$ by $492 \mathrm{~m}$ ). Seed was purchased from a commercial seed provider. We recorded seedling emergence and establishment in mid-June of 2001, 2004, and 2007 from 10 randomly selected quadrats per treatment.

The BLM Ely District constructed a 10-acre grazing exclosure at each of the four study sites. Two study sites are located in Newark Valley in east-central Nevada (Strawberry and Basque Well), with two more sites bordering Utah in Spring Valley (Spring Valley North and South). Each site has its own unique soils and plant communities that present the range professional with different challenges.

\section{Spring Valley North, Site \#1}

This was our most challenging site. The exclosure was surrounded by halogeton-dominated rangeland in poor ecological condition (Fig. 2). In many areas the site was sufficiently degraded as to prevent halogeton establishment. The site received an average of 6.6 inches $(168 \mathrm{~mm})$ of precipitation annually from 1999 through 2006, ranging from 4.1 inches to 9.5 inches $(104-241 \mathrm{~mm})$. In addition to being the most arid of the four sites, Spring Valley North has the highest concentrations of sodium in the soil surface. We had no success with our seeding efforts at this site.

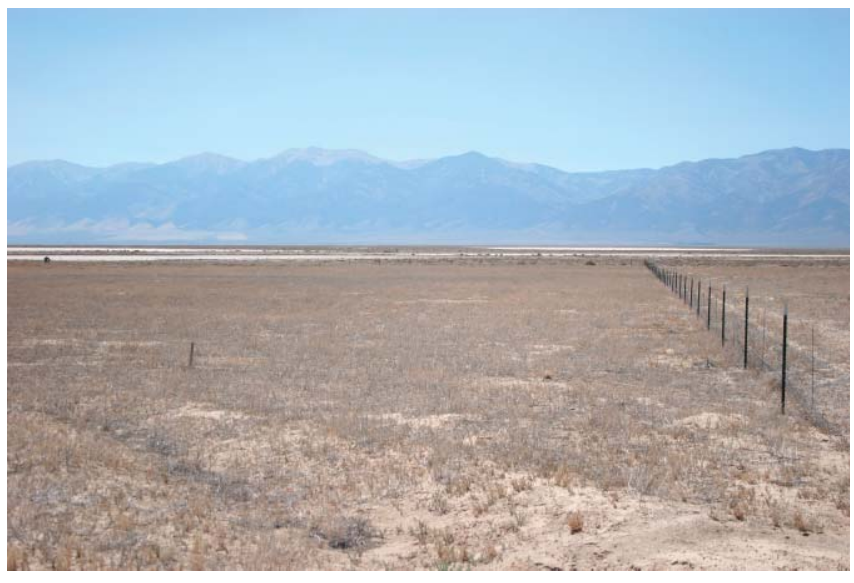

Figure 2. During many years not even the noxious weed halogeton will grow in this harsh environment at our Spring Valley North exclosure.

As with all four sites, the area surrounding this site is grazed during winter. Two decades prior to this study, the site was used for winter sheep grazing during moderate winters, or as fall and spring sheep grazing range as sheep were trailed from the desert of southern Nevada during more severe winters. We define winter grazing on these ranges as starting in the fall with dormant vegetation and ending about 1 February, when there is usually soil moisture available for the winterfat plants to grow and subsequently flower. Actual grazing on the sites during this study ranged from early fall through mid-spring to nearly year-round. Stock water for cattle on this range is provided by wells, whereas sheep previously used snow as a mid-winter water source.

\section{Spring Valley South, Site \#2}

This site was largely surrounded by winterfat communities in good to excellent ecological condition (Fig. 1). Soils were very similar to the Spring Valley North site, with less erosion and sodium concentrations. Winterfat seedling establishment was evident inside and outside of the exclosure, but despite the good to excellent ecological condition, there were areas where winterfat had died out and halogeton had become established. Initial seedling emergence was very promising, 10-20 seedlings per square foot (33-66 seedlings $/ \mathrm{m}^{2}$ ), as was first-year seedling survival (e.g., winterfat $=0.45$ seedlings per square foot or 19,890 seedlings per acre [1.49 seedlings $/ \mathrm{m}^{2}$ or 7,956 seedlings/ ha]). Following two consecutive years of heavy drought in 2002 and 2003 with less than 6 inches $(152 \mathrm{~mm})$ precipitation each year, our initial success decreased drastically (e.g., winterfat $=816 /$ acre $[326 /$ ha $]$; Table 1 ). A lack of summer precipitation likely caused these seedlings to die off. Without favorably timed precipitation, rangeland seedings are doomed to fail in harsh environments, even with good seedling emergence. During the driest years, halogeton failed to grow on areas it previously dominated at this site. 


Table 1. Initial seedling establishment from the fall 1999 rangeland drill-seeding effort, data recorded fall
$\mathbf{2 0 0 1 / 2 0 0 4 / 2 0 0 7}$

Later, when precipitation conditions were more favorable, barbwire Russian thistle (Salsola paulsenii) dominated the site rather than halogeton.

\section{Strawberry, Site \#3}

This site bordered extensive areas of winterfat communities in moderate to poor ecological condition. The predominant soil was a fine silt, although there were scattered dunes of fine sand that supported rabbitbrush (Chrysothamnus spp.) plants. Besides halogeton, other plant species posing problems at this site were annual kochia (Kochia scoparia), Russian thistle (Salsola tragus), and barbwire Russian thistle. Again, we initially seeded this site in the fall of 1999 using the same replicated design and species previously described for the other sites. Results were promising through 2001 (Table 1), especially for squirreltail, 'Hycrest' crested wheatgrass, and 'Immigrant' forage kochia. The site received on average nearly 11 inches $(279 \mathrm{~mm})$ of precipitation from October 1999 through September 2001, but 2002 and 2003 yielded less than 8 inches $(203 \mathrm{~mm})$ of precipitation annually. Annual broadleaf weeds at this site became established and appeared to negatively affect seeded species. In the big sagebrush (Artemisia tridentata) zone, it was our experience that successful establishment of perennial grasses limits the invasive annual broadleaf weeds and that the weeds largely disappear by the second year after seedling establishment. Apparently, winterfat environments are different and have a lower environmental potential; therefore, perennial grasses take longer to fully occupy the site. We tested the possible competitive effects of broadleaf annuals such as Russian thistle and halogeton on the establishment of seeded perennial grasses by applying 0.5 pounds per acre $(0.57 \mathrm{~kg} / \mathrm{ha})$ of $2-4 \mathrm{D}$, a selective broadleaf herbicide, across a 12 -foot wide portion of all the plots in May of 2001. The effect of this superimposed application of $2-4 \mathrm{D}$ was dramatic. The perennial grasses in untreated areas were completely dry or dormant in October, whereas the perennial grasses in the treated portion of the plots were green and robust. We assumed that we were sacrificing the 'Immigrant' forage kochia plants when we oversprayed the plots with $2-4 \mathrm{D}$, but to our surprise, already established 'Immigrant' forage kochia survived the herbicide application and responded vigorously to the resulting release from competition for resources.

\section{Basque Well, Site \#4}

This site was formerly surrounded by winterfat stands in excellent condition. The condition of these stands had declined during the last 25 years. Back in the late 1980s we visited this site with Wayne Burkhardt, formerly with University of Nevada-Reno. There was no apparent pattern to the mosaic die-off of winterfat back then, and the die-off has only expanded. We questioned whether these die-offs were a result of improper livestock grazing, an unidentified pathogen, climatic change, all of the above, or the combination of these and some other factors. These questions remain today. Cheatgrass (Bromus tectorum), halogeton, and tansy mustard (Descurainia pinnata) on this site presented additional challenges. On years with favorable precipitation this site had significant potential as perennial grasses, including Indian ricegrass and squirreltail, were abundant along with occasional patches of needle-and-thread grass. The native perennial forb globemallow (Sphaeralcea spp.) was abundant during good years as well. This site was also seeded in the fall of 1999 with excellent initial results (Table 1), especially 'Immigrant' forage kochia (Fig. 3). Siberian and 'Hycrest' crested wheatgrass along with squirreltail also had good initial success, but experienced the same fate as the Spring Valley South site when the drought occurred.

The presence of cheatgrass at this site resulted in greater competition. To control broadleaf annuals such as Russian thistle and halogeton, 2-4D was applied in the same manner as at the Strawberry site. This application of 2-4D did not affect the dense stand of cheatgrass that effectively competed with perennial grasses for essential resources. Here 'Immigrant' forage kochia plants that survived the herbicide application did not flourish. 


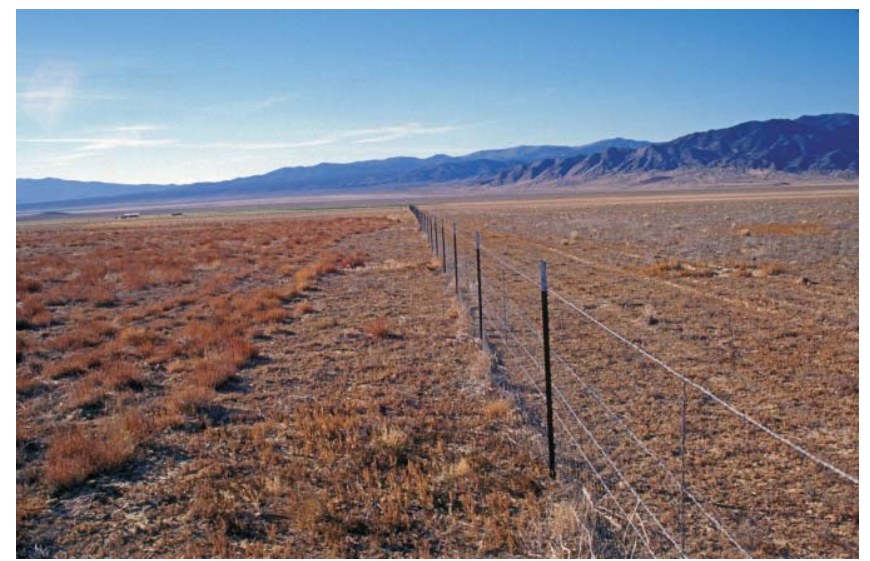

Figure 3. We have experienced excellent success seeding 'Immigrant' forage kochia (on the left), especially at our Basque Well study site.

\section{Conclusions}

Anyone that has ever attempted to restore or revegetate rangelands understands how difficult it is to experience success over failure and the frustrations associated with this daunting task. These degraded winterfat communities are of no exception, yet we are encouraged by our experiences when looking back at others who have attempted the same daunting task. The late range scientist Perry Plummer was one of the early pioneers in rangeland restoration, and he often commented on the wearisome difficulties of restoring winterfat communities. The fact that winterfat communities are primarily located in xeric, saline soils limits the potential for restoration, making the task more challenging. At the beginning of this study, there was only one site (Newark Valley North) where halogeton was actively replacing winterfat. Yet over time we witnessed a decline in winterfat densities with a subsequent increase in halogeton and other less desirable species. This occurred even when large herbivores were excluded.

It is important to note that winterfat sites are immensely variable, with significant differences in site potential due to soils and precipitation. Seeding these sites was extremely risky, as demonstrated by our lack of success at one of our sites (Spring Valley North), and only limited success at the other three sites (Table 1). Our results do indicate a potential to establish perennial grasses and 'Immigrant' forage kochia despite the harsh conditions. It is difficult to establish winterfat artificially, yet on years where the periodicity of precipitation is favorable in April, May, and June, winterfat seedlings stand a chance of being recruited into the community. Adjacent to the Spring Valley South site are winterfat densities approaching 300,000 per acre $(750,000 /$ ha). During the spring of 2000 we visited the site with local land managers that were excited about our early successes. Yet, our seeded winterfat densities were only 20,000 per acre $(50,000 / \mathrm{ha})$; obviously we had a long way to go.

The presence of competitive and exotic species often required further interventions. Seedling recruitment at sites with the lowest potential were episodic with a low probability of success. To improve the probability of success it is often essential to control competitive species such as halogeton, Russian thistle, barbwire Russian thistle, and annual kochia. This control increases much needed water and nutrients for successful reseeding efforts. Because resources are so limited, it is important not to use heavy seeding rates. Although initial germination and sprouting of seeded species may be widespread, their density may exceed what the site can support. At our Basque Well site we experienced excellent recruitment of 'Immigrant' forage kochia in plots where we seeded at a rate of 1 pound per acre $(1.13 \mathrm{~kg} / \mathrm{ha})$, yet when we hand-seeded at a rate of 2 pounds per acre $(2.26 \mathrm{~kg} / \mathrm{ha})$ in our observational rototilled plots, we initially recorded very high densities that soon declined rapidly and, in the end, were much lower than that of the lower seeding rate. We attributed this to initial stand densities greater than the site could support.

Restoration or revegetation of winterfat communities is critical to support the sustainability of these grazing lands for free-roaming horses, wildlife, and the range livestock industry. But one must recognize the difficulties of attempting to restore or revegetate degraded rangelands in harsh environments. It is also important to recognize degradation early on; perhaps a threshold was passed in front of our very eyes and these belated retoration or revegetation practices would have been more successful if they had been attempted at an earlier stage of degradation. Our approach has been to experimentally investigate the challenges that resource managers are likely to endure when attempting to restore or revegetate degraded winterfat communities and to find ways to overcome these challenges. By applying numerous approaches to small-scale plots and learning from those experiments, we can better inform resource managers of what lies ahead, and hopefully they can learn from our efforts and avoid the costly failure of some of these restoration or revegetation efforts on thousands of acres of degraded winterfat communities.

\section{References}

1. Young, J. A., And B. A. Sparks. 2002. Cattle in the Cold Desert. Reno, NV, USA: University Nevada Press. 317 p.

2. Monsen, S. B., R. Stevens, and N. L. Shaw. 2004. Restoring western ranges and wildlands. Fort Collins, CO, USA: USDA, Forest Service, Rocky Mountain Research Station. General Technical Report RMRS-GTR-136-vol. 884 p.

Authors are Rangeland Scientist, Charlie.Clements@ars.usda. gov (Clements), Retired Rangeland Scientist (Young), and Agricultural Research Technician (Harmon), US Dept of Agriculture, Agricultural Research Service, 920 Valley Road, Reno, NV 89512, USA; and Agricultural Extension Educator, University of Nevada Cooperative Extension, Eureka, NV 89316, USA (McCuin). 